\begin{tabular}{|c|c|}
\hline $\begin{array}{l}\text { Univerzitet u Beogradu } \\
\text { Poljoprivredni fakultet } \\
\text { Institut za poljoprivrednu tehniku }\end{array}$ & $\begin{array}{r}\text { University of Belgrade } \\
\text { Faculty of Agriculture } \\
\text { Institute of Agricultural Engineering }\end{array}$ \\
\hline $\begin{array}{l}\text { Naučni časopis } \\
\text { POLJOPRIVREDNA TEHNIKA }\end{array}$ & $\begin{array}{r}\text { Scientific Journal } \\
\text { AGRICULTURAL ENGINEERING }\end{array}$ \\
\hline $\begin{array}{l}\text { Godina XLVI } \\
\text { Broj 3., } 2021 . \\
\text { Strane: } 23-39\end{array}$ & $\begin{array}{l}\text { Year XLVI } \\
\text { No. 3., } 2021 . \\
\text { pp: } 23-39\end{array}$ \\
\hline
\end{tabular}

\title{
A REVIEW OF BIOREREMEDIATION OF HYDROCARBON CONTAMINATED SOILS IN NIGER DELTA AREA OF NIGERIA
}

\author{
Ehiomogue O. Precious ${ }^{* 1}$, Ahuchaogu I. Israel ${ }^{2}$, Ahaneku I. Edwin ${ }^{1}$ \\ ${ }^{I}$ Department of Agricultural and Bioresources Engineering, College of Engineering and \\ Engineering Technology, Michael Okpara University of Agriculture, \\ Umudike, Abia State, Nigeria. \\ ${ }^{2}$ Department of Agricultural and Food Engineering, Faculty of Engineering, \\ University of Uyo, Akwa-Ibom State, Nigeria.
}

\begin{abstract}
Bioremediation technologies are an environmentally friendly approach for the treatment of polluted soils. This review take a look at the various remediation efforts by various scientist to ameliorate the effect of crude oil contamination on the environment. Contamination of the total environment (air, soil, water and biota) by crude oil has become a paramount interest in the Niger Delta region of Nigeria. With the frequent reports of oil spillages in the Niger Delta area, there is need to seek for a cost effective method for remediation of crude oil impacted soils. Studies have revealed variable impacts of oil toxicity on the environment and exposed populations. Soil contamination is caused mainly by the leakage of underground storage tanks and pipes. The most common conventional method for the remediation of contaminated soils is excavation followed by landfilling or incineration and other technologies that have been widely practiced. Contaminated sites pose a threat to human life due to severe health problems caused by adverse health effects from exposure to soil contamination. Once it is being detected, assessment strategies, type of sampling, chemical analyses, evaluation of parameters and its effect must be done. Several technologies and parameters have been developed to treat petroleum hydrocarbon contaminated soil but the problem still exists.
\end{abstract}

Key words: Petroleum hydrocarbons, Natural attenuation, Bioaugmentation, Phytoremediation, Biopiles.

*Corresponding Author. E-mail address: ehiomogue.precious@mouau.edu.ng 


\section{INTRODUCTION}

Persistent release of petroleum hydrocarbons, toxic chemicals, and industrial waste have a detrimental impact on human health and environment. Oil contaminated soil in and around exploration and spillage areas are still a major environmental problem. The effect of oil spill has been frequently felt in the Niger Delta region of Nigeria. It is reported that the agricultural land near the oil exploration sites are often contaminated by hydrocarbons and land become unfit for agricultural cultivation [1]. Hydrocarbon contamination of the environment generally occur due to exploration, processing, and transportation of refine and unrefined product from one location to another. However, historic and ongoing human activities have resulted in large-scale contamination of lands, and in worst case scenario hitherto useful lands are transformed to wasteland [2]. Contamination of soils with petroleum hydrocarbons is one of the attendant environmental problems associated with industrialization and the dependence on petroleum and its by-products. One of the major agencies that have caused habitat destruction and modification i.e. ecosystem alterations is industrialization and technology, through air, water, and land pollution.

Soil contamination with petroleum hydrocarbons can be defined as any earthen material or artificial fill that has human or natural alteration of its physical, chemical, biological or radiological integrity resulting from the introduction of crude oil, any fraction, or derivative thereof (such as gasoline, diesel or motor oil, or oil base product $[3,4]$. The natural environment may be altered or even exterminated by man through series of agencies and effects. In the petroleum industry for example, pollution of the environment may occur through effluent discharges and accidental oil spillages. Studies indicate that subtle changes occur in the Nigeria aquatic and terestrial ecosystems due to the activities of the oil industries [5]. These studies in Nigeria reveals that the development and production processes in the oil and gas industries require an urgent need to plan, protect, and prudently ultilize environmental resources for a better environment for man. Most of the environmental changes occur from the release of crude oil into the environment. Thus, considerable attention has been paid to develop suitable techniques for effective remediation [6,7]. Over the last three decades, extensive studies have been conducted using different technologies including coagulation and flucculation, phytoremediation, reverse and forward osmosis, chemical oxidation, photocatalytic degradation and adsorption, $[8,9,10]$.

\section{MATERIAL AND METHODS}

\section{Soil Contamination}

Soil contamination is a global problem that constitutes significant threat to human and environmental health both in the present and in the future. Soil contamination has been an important topic in many areas of research, practice and policy within different countries which has also been extended internationally, [11]. The attached importance to contaminated soil has been increasing over the years. Increased population growth and industrialization around the world are key factors responsible for the increase in the contamination of soil and the environment which negatively affects various human health, wildlife, and microorganisms. 
The contaminant sources are waste disposal sites, mining sites, crude oil refineries and exploration, chemical application in agriculture, use of wastes water for irrigation, industrial emissions and maintenance, [12]

Contaminant can be any element that has the potential of causing harm on the environment. Environmental contamination is primarily interested in the physical, chemical or biological agents or their combinations that may pose a threat to life, health, safety or welfare of organisms in the environment. Soil contamination is the existence of these contamination above permissible limits at which deterioration or loss of soil functions occur, [13]. Major areas of soil contamination and pollution have been highlighted by [14] as follows:

I. Radioactive pollution of the soil. Accidental release of radioactive substances has been discovered in some part of the world. The substances are very harmful to the soil and provide an unsafe environment for human life and living organisms. There is currently serious concern over the risk of soil pollution on food safety and the sustainability of agricultural production across the globe. Fears of the food chain being compromised by soil pollutants are eminent as the consumption of food crops contained with pollutants remained a major suspect in food poison. Several studies have linked serious human health challenges to heavy metal accumulation by plants from contaminated soils, [15,16,17,18]

II. Soil acidification through the accumulation of acid from phosphate fertilizer, carbon, nitrogen and Sulphur cycles, and acid rains. Soil acidification lowers the soil $\mathrm{pH}$ and alters the soil chemistry. When the soil $\mathrm{pH}$ is reduced, the bioavailability of heavy metals in the soil is increased and a harmful environment for biological activities is created, the breakdown of nutrients for plant uptake is also hindered and the food chain compromised.

III. Direct introduction of toxic elements and compounds such as petroleum hydrocarbon and other dangerous organic compounds. This contributes to making the soil unsafe and creates an impediment in its functions.

\section{Soil Contamination by Petroleum hydrocarbons}

The word petroleum means rock oil or oil from the earth. Petroleum hydrocarbon is a term used to describe a large family of several hundred chemical compounds that originally come from crude oil. This mixture of chemicals can be described by common chemical characteristics such as boiling point ranges or size of the molecules. Petroleum hydrocarbon is a complex substance formed from hydrogen and carbon molecules and sometimes containing other impurities such as oxygen, Sulphur, and nitrogen, heavy metals and oxygen compounds. Examples of petroleum hydrocarbon contaminants are total petroleum hydrocarbons (TPHs) and polycyclic aromatic hydrocarbons (PAHs). Soil contamination with petroleum hydrocarbons is one of the adverse environmental problems associated with crude oil exploration in any part of the globe. Natural gas, Crude oil, tars and asphalt are types of petroleum hydrocarbons, [19]. 
Total petroleum hydrocarbons (TPHs) are used to describe mixture of organic compounds found in or derived from crude oil that has the potential to be very toxic (CCME, 2001). Total petroleum hydrocarbons can generally be divided into three fractions: (i) aliphatic, (ii) aromatics and (iii) polar and asphaltenes [20]. When soil is contaminated by petroleum hydrocarbons, the soil will have insufficient aeration due to the displacement of air from the spaces or pores between the soil particles. The displacement of air in the soil pores by petroleum hydrocarbons will cause anaerobic environment in soil by smothering soil particles and blocking air diffusion in the soil pores and affect the soil microbial communities negatively [21,22,23].

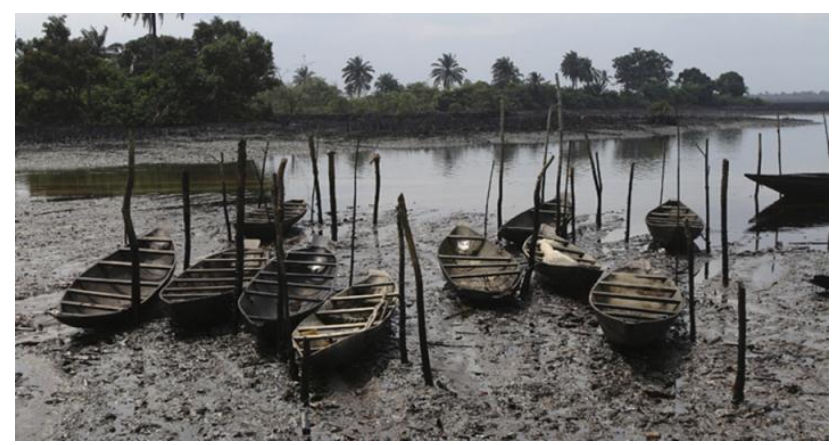

Figure 1. Crude-oil contamination in the Niger Delta area of Nigeria

Most product that contain total petroleum hydrocarbons (TPHs) are naturally volatile. Some are clear or light colour liquids that evaporate easily and others, are thick, dark liquids or semi-solid that do not evaporate and many of these products (gasoline, kerosene, etc.) have oily odours, [24]. The composition of petroleum hydrocarbons (PHCs); varies slightly by its source, but the toxic properties are consistent. Chemicals such as benzene and polycyclic aromatic hydrocarbons (PAHs) are extremely toxic components of serious concern [25]. Table 1 shows the percentage of elements and hydrocarbon contaminants present in crude oil.

Table 1. Percentage of elements and hydrocarbons present in the crude oil, [26].

\begin{tabular}{ccccc}
\hline \multicolumn{2}{c}{ Major components of crude oil } & \multicolumn{3}{c}{ Hydrocarbons present in crude oil } \\
Element & Weight $(\%)$ & Hydrocarbons & Weight $(\%)$ & Range \\
\hline Carbon & $84-87$ & Alkanes (Paraffins) & 30 & $15-60$ \\
Hydrogen & $11-14$ & Naphthenes & 49 & $30-60$ \\
Nitrogen & $0.1-2.0$ & Aromatics & 15 & $3-30$ \\
\hline Oxygen & $0.1-2.0$ & & & \\
Sulfur & $0.06-2.0$ & Asphaltic & 6 & Remainder \\
\hline
\end{tabular}

\section{Soil Remediation}

Soil remediation is any operation that can reduce the concentration of the contaminant, through chemical, biological or physical means in order to reduce the amount, and the mobility of the contaminant to an acceptable permissible concentration. The remediation of contaminated soils has become a serious concern and has created huge challenges globally in recent years. 
Although environmentalists, engineers, and various stakeholders have made considerable efforts to deal with the remediation issues, the problem has persisted. This may be likely, due to population increase. Remediation of contaminated soils is targeted at reducing the risk associated with pollutant and improving the quality of the environment while complying with regulatory requirements.

Various methods and technology have been proposed by many researchers and government agency, [27,28,29]. Existing publications have indicated that the major degradation of TPH occurs in the aliphatic fraction, [30]. The aromatic fraction appears to be reduced with relatively low efficiency, and the polar and asphaltene fraction frequently accumulates in the later stage of degradation, [31,30].

\section{Bioremediation}

Bioremediation is a process that allows the remediation of harmful/toxic chemicals by natural processes [29]. It exploits the metabolic diversity and adaptation of microbes for degrading and transforming various organic and inorganic contaminants [32]. For practical application of bioremediation to be considered, there should be a demonstration that the removal of contaminants is the primary effect of bioremediation and that the degradation rate is greater than the natural rate of decontamination [33]. For practical application of bioremediation to be considered, there should be a demonstration that the removal of contaminants is the primary effect of biodegradation and that the degradation rate is greater than the natural rate of decontamination [33]. Since microbes existing in soils/groundwater feed on certain chemicals, the complete digestion of this chemicals by microbes convert them into water and gases such as $\mathrm{CO}_{2}$ [34]. Commonly used organisms for this purpose are bacteria, fungi or protozoa either natural occurring or genetically modified, [35]. Organisms have been widely studied and shown to destroy organic chemicals, whereas they can either remove or convert to stable form. For bioremediation to be successful, it is important to ensure that the correct environmental conditions are in place to maximize the growth and activity of the microbes. These conditions include nutrient content, soil structure and texture, temperature and oxygen content as well as the correct assemblage of the microorganisms, [36]. If these conditions are not met, the microbes could grow too slowly, die or even create more harmful chemicals, [37]. Different kinds of bioremediation methods have been developed to reduce the time required for degradation and reduce cost by increasing the derivative activity of native microbial populations, [38]. These approaches include the following which can be in-situ or ex-situ.

\section{Biostimulation}

Biostimulation involves the addition of oxygen or mineral nutrients to stimulate the numbers and activities of natural populations, usually bacteria and fungi so that they can break down pollutants into harmless products, [38]. In most environments, the presence of nitrogen and phosphorous is limited, even when total concentrations are high, it may be in a mineral form that is biologically unavailable, [39].

Therefore, Biostimulation accelerates the decontamination rate as the addition of one or more rate limiting nutrients improves the microbes degrading potential, [40]. 
Nitrogen and phosphorous has been widely used in Biostimulating processes to support growth of microorganisms, [41] showed that the addition of nitrogen and phosphorous as inorganic fertilizer and the addition of biosolids enhanced the biodegradation of petroleum hydrocarbon by up to $96 \%$.

However in some cases, addition of nutrients can negetively affect the microoganisms and biodegradation is suppressed. [42] showed that phenanthrene mineralization rates were depressed or remained the same with the addition of nitrogen and phosphorous to phenanthrene-contaminated soil.

This could be as a result unbalanced or inapropriate level of nutrients, adsorption of the pollutant to the medium (soil) that prevents the availability of the pollutants for destruction or inactivity of the indigenous microbes caused by high concentration of pollutants.

\section{Bioaugumentation}

The success of bioremediation usually requires the application of strategies that are specific to the particular environmental conditions of the contaminated sites. Bioaugumentation which includes the addition of pre-adapted consortium, introduction of genetically engineered bacteria or the addition of biodegradation relevant genes packaged in a vector to be transferred $b$ conjugation into indigenous microorganisms plays a major role during biodegradation [43]. From an application perspective, using microbial consortiouminstead of a pure culture for bioaugumentation ia advantageous [44]. Two factors limit the use of added microbial pure cultures for contaminated land treatment. Firstly, the non-indigeneous cultures are unable to compete properly with the indigenous population to develop useful population level and secondly, most soils that have been exposed to biodegradable contaminants for a long period have indigenous microorganisms that can effectively degrade the contaminant if treatment is properly managed [45]. Although this method of remediation is simple, there have been many records of failures. [46] showed that there was no improvement on nitrogen removal when a nitrifying batch reactor was inoculated two times with areobic dentrifying bacteria even after addition of acetate as a nutrient. Nevertheless, some work has shown promise for the strategy of combining both bioaugumentation and biostimulation to enhance bioremediation [43]. [47] successfully obtained complete degradation of diesel oil and phenanthrene to an overall $75 \%$ reduction of the total hydrocarbon in 42 days. Indigeneous and exogenous microbes could benefit from the addition of energy sources or electron-acceptors.

[48] with their development of a combined bioaugumentation and biostimulation process for treatment of site highly contaminated with atrazine, showed that bioaugmentation with Pseudomonas $s p$ strain ADP and citrate or succinate biostimulation increased atrazine mineralisation.

\section{Composting}

This method is based on ancient method of turning household waste into usable organic amendments. It useds the biological system of microbes in the compost to breakdown or transform contaminants in soil/water [49]. This method of remediation has received little attention even though it has been used for treatment of contaminated soils for many years [50]. 
Most of the work has been carried out on low levels of contamination although compost has shown potential for remediation of heavily contaminated sites [51].

Many contaminants like Petroleum Aromatic Hydrocarbons (PAH) [52], heavy metal [53] and pesticides [54] have been remediated by this method. [52] showed that after 42 days of composting, 35 to $68 \%$ of both 3 to 4 rings and other higher molecular mass PAH were removed.

Metallic contaminants are not degradable, therefore during composting, they are converted into organic combinations that are less bioavailable than the mineral combination of the metals [53]. [55] showed that during composting of biosolids and municipal wastes, there was a decline in soluble components of metal like Zinc ( $\mathrm{Zn}$ ), Chromium $(\mathrm{Cr})$, Copper $(\mathrm{Cu})$ and an increase in residual, organically bound forms. Compost remediation works in the same way as the biological process of soil remediation. As there is increased temperature in compost than in soil, there is increased solubility of contaminants in compost than in soil, there is increased solubility of contaminants in compost which increase destruction of contaminants helped with an increase and diversity of microbial population [53]. Microbes play an important role from the beginning to the end of composting. Their increase and diversity are controlled by changes in levels of moisture, temperature and nutrients, these ensure that the contaminants are exposed to a wider range microbe-environment conditions [56]. Although composting has been effective [57], its vulnerability to high concentration (>2500 ppm) of heavy metal (microbial growth could be inhibited), its requirement for impermeable liners and its requirement for large area of land for treatment has limited its use [58].

\section{Land Farming}

This is an ex-situ remediation method that involves the application of contaminates soil to the land surface and with periodic mixing with agricultural equipment contaminant biodegradation is achieved [59]. Contaminants such as total petroleum hydrocarbon (TPH) can also be volatilized using this process [60]. Tilling of the soil periodically disrupts the aggregate, which accelerates nutrient and contaminant distribution throughout the soil while providing oxygen to the soil [59]. As microbes in soil have diverse catabolic activities, adding compounds containing microbes to the contaminated sites leads to pollutant degradation [61]. Cover crops could be planted during land farming remediation. This would enhance rhizosphere degradation [54]. Land farming is slow because the conditions that affect degradation such as temperature and rainfall are uncontrolled [62], it is low cost technology. The rate of application is calculated and the size of land is based on the application rate. This is done to avoid concentrations that would be detrimental to the soil [63]. Most land farming remediation reqiures the addition of nutrients to accelerates degradation by indigenous microbes. With the addition of fertilizer, biodegradation was enhanced and enough hydrocarbons were degraded when land farminf was applied on hydrocarbon contaminated soil in the Canadian Arctic [60]. Although land farming is an effective remediation technique, it has its shortfalls. These include its remediation potential for inorganic since they are nonbiodegradable and the presence of haevy metal concentration of $2500 \mathrm{mg} / \mathrm{kg}$ or more may inhibit microbial growth. Volatile constituents may evaporate during aeration and could cause air pollution and its requires large land area for treatment. 
Dust generated could cause air pollution and it is difficult to achieve more than $90 \%$ contaminant reduction [62].

The process of reducing the petroleum constituents present in the soil by spreading the soils on the ground and stimulating aerobic microbial activity within the soils through aeration and/or the addition of nutrients, minerals, and water/moisture known as land farming is only effective in remediating lighter petroleum hydrocarbons $[64,65]$ as heavier hydrocarbon do not evaporate or microbially degrade through this process [64].

\section{Biopiles}

Biopiles is another commonly used treatment process for hydrocarbon contaminated soil. It is a method that involves the piling of petroleum-contaminated soils into piles or heaps and then simulating aerobic microbial activity by aeration and the addition of minerals, nutrients, and moisture [66]. The bio-piled soils are often subjected to heat and $\mathrm{pH}$ alteration to enhance biodegradation [64]. This method is similar to land farming, but in the latter, the soil is aerated through tilling and ploughing [66]. This treatment option is only effective in reducing light fractions of petroleum hydrocarbon in the soil, and does not also lead to complete removal or degradation of hydrocarbon from the soil [64].

\section{Phytoremediation}

Phytoremediation is a treatment method that uses plants to clean up hydrocarbon and other contaminants from the soil. The process takes advantage of the ability of some plants to take up, accumulate, and/or degrade constituents that are present in soil or process them for physiological processes $[64,67]$. Phytoremediation is a broad term that incorporates all the different processes that plant use to remove, transform or stabilize pollutants in soil, water or atmosphere. It is a plant-based remediation technology that is applied to both inorganic and organic contaminants in soil, water and sediments globally [68]. Naturally processes by which plants and their associated microbes degrade and/or sequester inorganic and organic pollutants are incorporated in this technology which makes it a cheaper and environmentally sustainable option to mechanical and chemical methods of removing contaminants from soil [68]. It also generates fewer secondary waste and less environmental impact than would be obtained using other traditional methods [69]. Results of research for phytoremediation potential show that it is applicable to a broad range of contaminants including metals [70], radionuclides [71], organic compounds for example, chlorinated solvents, BTEX (benzene, toluene, ethylbenzene and xylene) [72], polychlorinated biphenyl [73], polycyclic aromatic hydrocarbons (PAHs) [74] and pesticides [73]. 


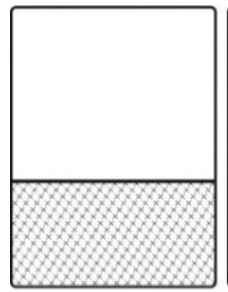

NATURAL ATIENUATION

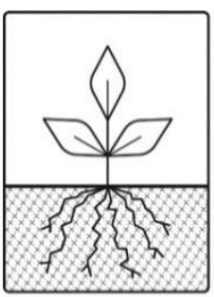

PHYTOREMEDIATION

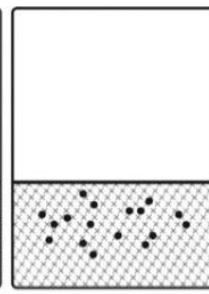

BIOAUGMENTAIION

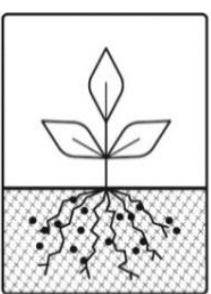

PHYTOREMEDIATION

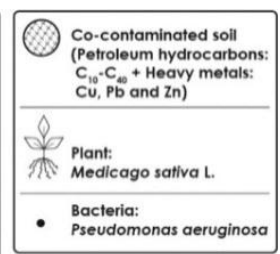
Psevdomonas aeruginosa

\section{$>$ Petroleum Hydrocarbon removal}

Figure 2. Different methods of petroleum hydrocarbon removal from contaminated soil, [75].

The term phytoremediation was not used until the 1980s although the use of plants to remediate radionuclide-contaminated soils was explored in the 1950s [76]. According to [77], numerous laboratory and greenhouse studies are carried out to determine plant toxicities and contaminant uptake abilities. In order for phytoremediation to achieve global acceptance as a remedial method, field scale applications need to be carried out and documented. There have been extensive studies on application of constructed wetlands and vegetative covers in the field to demonstrate their phytoremediation capabilities as well as field scale studies of the use of plants for ground water and soil remediation [78]. This process is time consuming, as the remediation may require more than one growing season; and the treatment is limited to soils less than one meter from the surface [79]. Table 2 showed the bioremediation of petroleum hydrocarbon by different researchers in the last two decades.

\section{RESULTS AND DISCUSSION}

Table 2. Relevant studies on crude-oil related contaminants remediation in Nigeria

\begin{tabular}{|l|l|l|l|l|}
\hline $\begin{array}{l}\text { Ser. } \\
\text { No. }\end{array}$ & $\begin{array}{l}\text { Material use for } \\
\text { remediation }\end{array}$ & Remediation type & Contaminants & Result \\
\hline 1. & $\begin{array}{l}\text { Earthworms } \\
\text { (Eudrillus } \\
\text { euginae and } \\
\begin{array}{l}\text { Lumbricus } \\
\text { terrestris) }\end{array}\end{array}$ & Vermiremediation & Crude Oil & $\begin{array}{l}\text { Activities of E. euginae led to } \\
88.50 \% \text { TPH loss, L. terrestris } \\
\text { led to 76.42\% loss while } \\
\text { combined activities of the two } \\
\text { earthworms led 73.06\% loss } \\
\text { of TPH from the soil } \\
\text { contaminated with 3ml crude } \\
\text { oil after 30days. }\end{array}$ \\
\hline 2. & $\begin{array}{l}\text { Corn and } \\
\text { Elephant grass }\end{array}$ & Phytoremediation & $\begin{array}{l}\text { Petroleum- } \\
\text { Hydrocarbon }\end{array}$ & $\begin{array}{l}\text { The results of the analyses } \\
\text { revealed average hydrocarbon } \\
\text { losses of 77.5\% (Z. mays) and } \\
83 \% \text { (P. purpureum) within the } \\
\text { first two weeks, these values } \\
\text { decreased to 67.5\% and 55\% } \\
\text { after the six-week remediation } \\
\text { period for corn and elephant } \\
\text { grass respectively. }\end{array}$ \\
\hline
\end{tabular}




\begin{tabular}{|c|c|c|c|c|}
\hline & & & & $\begin{array}{l}\text { On the other hand, the corn plus } \\
\text { elephant grass treatment } \\
\text { showed hydrocarbon losses of } \\
62 \% \text { and } 74 \% \text { for the two and } \\
\text { six-week period respectively. }\end{array}$ \\
\hline 3. & $\begin{array}{l}\text { Goat droppings } \\
\text { and NPK } \\
\text { fertilizer }\end{array}$ & $\begin{array}{l}\text { Biological and } \\
\text { chemical }\end{array}$ & $\begin{array}{l}\text { Petroleum- } \\
\text { Hydrocarbon }\end{array}$ & $\begin{array}{l}\text { It was observed that the } \\
\text { application of goat droppings } \\
\text { was able to ameliorate the } \\
\text { levels of total hydrocarbons } \\
\text { form } 7568 \mathrm{mg} / \mathrm{g} \text { to } 439 \mathrm{mg} / \mathrm{kg} \text { as } \\
\text { against } 500 \mathrm{mg} / \mathrm{kg} \text { produced by } \\
\text { NPK fertilizer which indicates a } \\
\text { better remediation in goat } \\
\text { dropping application. }\end{array}$ \\
\hline 4 & $\begin{array}{l}\text { Fertilizer and } \\
\text { oxygen } \\
\text { exposure }\end{array}$ & $\begin{array}{l}\text { Chemical and } \\
\text { Oxygen }\end{array}$ & Crude-Oil & $\begin{array}{l}\text { The hydrocarbon losses } 50- \\
95 \%) \text { experienced in the five } \\
\text { treatment-cells revealed the } \\
\text { effectiveness in degrading the } \\
\text { hydrocarbon contaminant. } \\
\text { The results of this study } \\
\text { indicate that the application of } \\
\text { increased concentrations of } \\
\text { nutrients (by the application of } \\
\text { fertilizers) lead to greater rates } \\
\text { of biodegradation of petroleum- } \\
\text { polluted agricultural soils. }\end{array}$ \\
\hline 5 & $\begin{array}{l}\text { Cladosporium } \\
\text { spp }\end{array}$ & Bioremediation & Hydrocarbon & $\begin{array}{l}\text { The Total hydrocarbon } \\
\text { concentration decreased for } \\
\text { both the sterilized and non- } \\
\text { sterilized sample after } \\
\text { bioremediation. Decrease in } \\
\text { concentration from } 1.87-1.41 \\
\mathrm{mg} / \mathrm{l} \text { and } 1.87-0.70 \mathrm{mg} / \mathrm{l} \text { for } \\
\text { sterilized and unsterilized } \\
\text { samples respectively. It could } \\
\text { also be depicted from this work } \\
\text { that Cladosporium functions } \\
\text { more effectively in the presence } \\
\text { of other microorganisms since it } \\
\text { has more effect in non-sterilized } \\
\text { sample than the sterilized } \\
\text { sample as clearly shown in the } \\
\text { percentage removal (56.00\%). }\end{array}$ \\
\hline 6. & $\begin{array}{l}\text { Cyperus } \\
\text { odoratus, } \\
\text { Colocasia } \\
\text { esculenta, } \\
\text { Phoenix } \\
\text { roebelenii } \\
\text { and Eisenia } \\
\text { fetida }\end{array}$ & $\begin{array}{l}\text { Phytoremediation } \\
\text { and } \\
\text { Vermiremediation }\end{array}$ & $\begin{array}{l}\text { Total } \\
\text { Petroleum } \\
\text { Hydrocarbon } \\
\text { in } \\
\text { contaminated } \\
\text { surface water }\end{array}$ & $\begin{array}{l}\text { At week } 5 \text {, TPHs } \\
\text { phytoremediation's in the } \\
\text { monoculture reactors removal } \\
\text { efficiency was ( } 31.28 \mathrm{mg} / \mathrm{L}) \\
99.97 \% \text { and mixed culture } \\
\text { indicated }(19.72 \mathrm{mg} / \mathrm{L}) 99.98 \% \text {; } \\
\text { while polyculture indicated } \\
(8.91 \mathrm{mg} / \mathrm{L}) 99.99 \% \text {. }\end{array}$ \\
\hline
\end{tabular}




\begin{tabular}{|c|c|c|c|c|}
\hline & & & & $\begin{array}{l}\text { The combination of } \\
\text { phytoremediation and } \\
\text { vermiremediation techniques in } \\
\text { polyculture reactors showed } \\
\text { better and spectacular results as } \\
\text { the biotas demonstrated good } \\
\text { potentiality of } \\
\text { hyperbioaccumulation to serve } \\
\text { as hydrocarbon sinks from the } \\
\text { ecotoxics of total petroleum } \\
\text { hydrocarbons. }\end{array}$ \\
\hline 7. & $\begin{array}{l}\text { Sheep waste } \\
\text { compost and } \\
\text { goat waste } \\
\text { compost }\end{array}$ & Bioremediation & Crude oil & $\begin{array}{l}\text { The results showed that all } \\
\text { bioremediation agents applied } \\
\text { enhanced the natural } \\
\text { bioremediation of the } \\
\text { contaminated soil and the most } \\
\text { preferred results were obtained } \\
\text { when treatments were done } \\
\text { using sheep waste compost. } \\
\text { This study revealed that the } \\
\text { remediation process was } \\
\text { influenced by application } \\
\text { period, type of oil, and compost } \\
\text { rate. }\end{array}$ \\
\hline 8. & $\begin{array}{l}\text { Moringa } \\
\text { Oleifera leave } \\
\text { extract }\end{array}$ & Bioremediation & Crude oil & $\begin{array}{l}\text { The application of Moringa } \\
\text { leave extract was found to be } \\
\text { useful in the enhancing of crude } \\
\text { oil polluted lands, and by so } \\
\text { doing it facilitates the } \\
\text { rehabilitation of the } \\
\text { contaminated soil as well as } \\
\text { reinstating the soil constituents } \\
\text { for agricultural purposes }\end{array}$ \\
\hline 9. & $\begin{array}{l}\text { Goat manure, } \\
\text { poultry } \\
\text { droppings and } \\
\text { cow dung }\end{array}$ & Bioremediation & Crude Oil & $\begin{array}{l}\text { The results of this study } \\
\text { indicated that nutrient } \\
\text { amendment can enhance the } \\
\text { rate of biodegradation of crude } \\
\text { oil polluted soil. }\end{array}$ \\
\hline 10 & $\begin{array}{l}\text { Mineral } \\
\text { fertilizers and } \\
\text { periodic } \\
\text { application } \\
\text { of different } \\
\text { amounts } \\
\text { of water }\end{array}$ & Bioremediation & $\begin{array}{l}\text { Petroleum } \\
\text { hydrocarbon }\end{array}$ & $\begin{array}{l}\text { Laboratory analysis of soil } \\
\text { characteristics showed an } \\
\text { increase in the } \\
\text { total heterotrophic bacterial } \\
\text { (THB) counts and a } \\
\text { corresponding reduction in soil } \\
\text { organic carbon and total } \\
\text { hydrocarbon content (THC) at } \\
\text { the endof the six-week } \\
\text { remediation period. }\end{array}$ \\
\hline
\end{tabular}




\begin{tabular}{|l|l|l|l|l|}
\hline & & & $\begin{array}{l}\text { The percentage of THC } \\
\text { reduction ranged from } 44 \% \text { to } \\
90 \% \text { in the five treatment cells }\end{array}$ \\
\hline 11. & $\begin{array}{l}\text { Enhance natural } \\
\text { attenuation } \\
\text { (RENA) }\end{array}$ & Bioremediation & Crude oil & $\begin{array}{l}\text { The gas-chromatography-flame } \\
\text { ionization detector (GC-FID) } \\
\text { results showed that the pollutant } \\
\text { concentrations (TPH and PAH) } \\
\text { reduced by 98 and } 85 \%, \\
\text { respectively, after the } \\
\text { remediation. }\end{array}$ \\
\hline
\end{tabular}

\section{CONCLUSION}

The natural environment may be altered or even exterminated by man through a series of agencies and effects. One of the major agencies that have caused habitat destruction and modification i.e. ecosystem alterations is industrialization and technology, through air, water, and land pollution. In the petroleum industry for example, pollution of the environment may occur through effluent discharges and accidental oil spillages. Environmental studies in Nigerian reveal that the development and production processes in the oil industry require an urgent need to plan, protect, and prudently utilize environmental resources for a better environment for man. Applying earthworms to a contaminated site might be an environmentally friendly way to remove hydrocarbons from soil. However, a limitation might be the cost of the large amounts of earthworms required to remove PAHs from soil and the necessity to supply them with sufficient substrate while maintaining the water content of the soil high enough for their normal functioning.

This review indicate that subtle changes occur in the Nigeria aquatic and terrestrial ecosystems due to the activities of the oil industry.

\section{REFERENCES}

[1] Deka, S., Devi, A., Barthakur, H., \& Kagti, L. 2004. Impact of oil exploration on physicochemical properties of rice field soil at Moran oil field of Upper Assam. International Journal of Environmental Protection, pp.273-276.

[2] Tinsley, A., \& Farewell , T. 2015. Soil degradation: a growing concern. Dissecting Soil: Safeguard an Invaluable Natural Resources. The Environmental, IEMA, UK, pp.14-17.

[3] Chukwuma , M. C., Eshett, E. T., Onweremadu, E. U., \& Okon , M. A. 2010. Zinc availability in relation to selected soil properties in a crude oil polluted eutric tropofluvent. Int. Journal of Environmental Science Technology, 7(2), pp. 261-270.

[4] Rafaat, A. A. 2010. Diffferent techniques for the production of biodiesel from waste vegetable oil. Int.Journal of Environmental Science Technology, 7(1), pp.183-213.

[5] Onyenjoro, C. 2011. Modelling the Rate of Degradation in Crude Oil Polluted Sites. University of Nigeria , Dep.of Civil Engineering . Nsukka: University of Nigeria .

[6] Wang, F., Haftka, J., Sinnige, T., Hermens, J., \& Chen, W. 2014. Adsorption of polar, nonpolar, and sustituted aromatics to colloidal graphane oxide nano particles. Environmental Polution, 186, pp.226-233. 
[7] Zhou , L., Meng, X., Fu, J., Yang, Y., Yang, P., \& Mi, C. 2014. Highly efficient adsorption of chlorophenols onto chemically modified chitosan. Applied Surface Science, pp.735-741.

[8] Blanchard, M., Teil , M., Ollivon , D., Legenti, L., \& Chevreuil, M. 2004. Polycyclic aromatic hydrocarbons and polychlorobiphenyls in wastewaters and sewage sludges from the Paris area (France). Environmental Research, 95(2), pp.184-197.

[9] Mojiri, A., Zhou, J., Ohashi, A., Ozaki, N., \& Kindaichi, T. 2019. Comprehensive review of polycyclic aromatic hydrocarbons in water sources, their effects and treatment. Science of The Total Environment, 696, pp.9-14. doi:10.1016/j.scitotenv.2019.133971

[10] Lamichhane, S., Bal Krishna , K., \& Sarukkalige, R. 2016. Polycyclic aromatic hydrocarbons removal by sorption: A review. Chemossphere, 148, 336-353. doi:10.1016/j.chemosphere.2016.01.036

[11] Troeh, F. R., Hobbs, J., \& Donahue, R. L. 1981. Soil and Water Conservation for Productivity and Environment Production. Soil Science, 88, pp. 299-309.

[12] Zhan, X., Wang, H., He, L., Lu, K., Sarmah, A., Li, J., Huang, H. 2013. Using Biochar for Remediation of Soils Contaminated with Heavy Metals and Organic pollutants. Environmental Science and Pollution Research, 20, 8472-8483.

[13] Cottenie, A., Verloo, M. 1984. Analytical Diagnosis of Soil Pollution with Heavy Metals. Environmental Research and Protection, https://doi.org/10.1007/978-3-642-69777-7_44. pp.389-393.

[14] Blum, W. E. 1990. The Challenge of Soil Protection in Europe. Environmental Conservation, 17, pp. $72-74$.

[15] Lente , I., Keraita , B., Drechsel, P., Ofosu-Anim, J., \& Brimah, A. K. 2012. Risk Assessment of Heavy Metal Contamination on Vegetables Grown in Long-Term Wastewater Irrigated UrbanFarming Sites in Accra, Ghana. Water Quality Exposure and Health, 4, pp.179-186.

[16] Muchuweti, M., Birkett, J., Chinyanga, E., Zvauya, R., Scrimshaw, M. D., \& Lester, J. 2006. Heavy Metal Content of Vegetables Irrigated with Mixture of Wastewater and Sewage Sludge in Zimbabwe: Implications of Human Health. Agricultural Ecosystem and Environment, 112, pp. 41-48.

[17] Khan, S., Cao, Q., Zheng, Y., Huang, Y., \& Zhu, Y. 2008. Health Risk of Heavy Metals in Contaminated Soils and Food Crops Irrigated with Wastewater in beijing, China. Environmental Pollution, 152, pp.686-692.

[18] Zhuang , P., McBride, M. B., Xia, H., Li, N., \& Li, Z. 2009. Health Risk from Heavy Metal via Consumption of Food Crops in the Vicinity of Dabraoshan Mine, South China. Science of the Total Environment, 407, pp.1551-1561.

[19] Frick, C. M., Farrell, R. E., \& Germida, J. J. 1999. Assessment of Phytoremediation as as InSitu Techniques for Cleaning Oil Contamination Sites. University of Saskatchewan, Department of Soil Science. Saskatoon: Petroleum Technology Alliance Canada. Retrieved March 21, 2020, from https://www.researchgate.net/publication/228592129_Assessment_of_phytoremediation _as_an_in-situ_technique_for_cleaning_oil-contaminated_sites

[20] Kang, Y. S., Park, Y. J., Jung, J., \& Park, W. 2009. Inhibitory effect of aged petroleum hydrocarbons on the survival of inoculated microorganisms in a crude-oil contaminated site. journal of microbiology and Biotechnology, 19, pp.1672-1678.

[21] Townsend, G. T., Prince, R., \& Suflita , J.2003. Anaerobic Oxidation of Crude Oil Hydrocarbons by the Resident Microorganisms of a Contaminated Anoxic Aquifer. Environmental Science and Technology, 37(22), 5213-5218. doi:10.1021/es0264495

[22] Labud, V., Garcia, C., \& Hernandez, T. 2007. Effect of Hydrocarbon Pollution on the Microbial Properties of a Sandy and a Clay Soil. Chemosphere, 66(10), pp. 1863-1871. 
[23] Sutton , N. B., Maphosa, F., Mirillo, J. A., Al-Soud, W. A., Langenhoff, A. M., Grotenhuis, T., Smidt, H. 2013. Impact of Long-Term Diesel Contamination on Soil Microbial Community Structure. Applied and Environmental Microbiology, 79(2), pp.619-630. doi:10.1128/AEM.02747-12

[24] Giller, K. E., Witter, E., \& McGrath, S. P. 1998. Toxicology of Heavy Metals to Mocroorganisms and Microbial Processes in Agricultural Soils: a review. Soil Biology and Biochemistry, 30, pp. 1389-1414.

[25] Kamath , R., Rentz, J. A., Schnoor, J. L., \& Alvarez, P. J. 2004. Phytoremediation of Hydrocarbon-contaminated Soils: Principles and Applications. Studies in Surface Science and Catalysis, 151, pp.447-478.

[26] Hyne, N. J. 2012. Nontechnical Guide to Petroleum Geology, Exploration, Drilling and Production. Tulsla, Oklahoma: Library of Congress Cataloging-in-Publication Data.

[27] Stegmann, R., Brunner, G., Colmano, G., \& Matz, G. 2001. Treatment of Contaminated Soil: Fundamentals, Analysis, Applications. Berlin Heidelberg: Springer-Verlag .

[28] Agency, U. S. 2001. A Citizens Guide to Bioremediation. pp. 44-65.

[29] BIOWISE. 2000. Contaminated Land Remediation : A Review of Biological Technology. Bio-Wise : Biotechnology at Work, pp. 1-23. Retrieved April 12, 2020, from https://www.staff.ncl.ac.uk/p.j.sallis/note819/biorem.pdf

[30] Oudot , J., Merlin, F. X., \& Pinvidic, P. 1998. Weathering rates of oil components in a bioremediation experiments in estuarine sediments. Marine Environment Resources, 45, pp.113-125.

[31] Chaineau, C. H., Moreb, J., Dupot, J., Bury, E., \& Oudot, J. (1999). Comparison of the fuel oil biodegradation potential of hydrocarbons-assimilating microoorganisms isolated from a temperate agricultural soil. Journal of Total Evironment, 227, pp.237-247.

[32] Cunninggham, \& Philip. (2000). Comparison of bioaugumentation and biostimulation in exsitu treatmrnt of diesel contaminated soil. Land Contamination and Reclamation, 8 pp. 261-269.

[33] Bento, F., Camargo, F., Okeke, B., \& Frankenberger, W. 2005. Comparative bioremediation of soils contaminated with diesel oil by natural attenuation, biostimulation and bioaugumentation. Bioresource Technology, 96, pp. 1049-1055.

[34] Azizi, A. B., Lim, M. M., Noor, Z., \& Abdullah, N. 2013. Vermiremoval of heavy metals in sewage sludge by ultilizing Lumbricus rubellus. Ecotoxicology and Environmental Safety, 90, pp. 13-20.

[35] Mathew, A. 2005. Phytoremediation of heavy metal contaminated soil. Oklahoma State University . Oklahoma: Unpublished MSc. Thesis.

[36] Baptista, S., Cammarota, M., \& Carvalho, D. 2005. Evaluation of the biostimulation of crude oil contamination clay soil. 2nd Mercosur congress on in chemical engineering, pp. 125-133.

[37] Adedokun, O. M., \& Ataga , A. E. 2007. Effects of Amendments and Bioaugumentation of Soil Polluted with Crude Oil, Automotive Gasoline Oil and Spent Engine Oil on the Growth of Cowpea (Vigna unguiculata L. Walp). Sciencee Research Essay, 2(5), pp. 147-149.

[38] Perfumo , A., Banat, I., Merchant, R., \& Vezzulli, L. 2007. Thermally enhance approaches for bioremediation of hydrocarbon contaminated soils. Chemoshpere, 66, pp. 179-184.

[39] Hazen, T. (2010). Handbook of Hydrocarbon and Lipid Microbiology. Berlin, Heidelberg: Springer-Verlag.

[40] Nikolopoulou, M., \& Kaloggerakis, N. (2009). Biostimulation strategies for fresh and chronically polluted marine environment with petroleum hydrocarbons. Journal of Chemical Technology and Biotechnology, 84, 802-807.

[41] Sarkar, D., Ferguson, M., Datta , R., \& Birnbaum, S. (2005). Bioremediation of petroleum hydrocarbons in contaminated soils: Comparison of biosolids addition, carbon supplementation, and monitored natural attenuation. En. Pollution, 136, pp.187-195. 
[42] Johnson, C., \& Scow, K. 1999. Effect of Nitrogen and Phosphorous addition on Phenanthrene biodegradation in four soils. Biodegradation, 10, pp. 43-50.

[43] El Fantroussi, S., \& Agathos, S. 2005. Is bioaugmentation a feasible strategy for pollutant removal and site remediation? Current Opinion in Microbiology, 8, pp.268-275.

[44] Nyer, E., Payne, F., \& Suthersan, S. 2002. Environment vs bacteria or let's play 'name that bacteria'. Ground Water and Monitoring Remediation, 23, pp. 36-45.

[45] Vidali , M. 2001. Bioremediation: An overview. Pure Applied Chemistry, 73, pp.1163-1173.

[46] Bouchez, T., Patureau, D., Dabert, P., Juretschko, S., Dore, J., Delgenes, P., Wagner, M. 2000. Ecological study of a bioaugmentation failure. En.Microbiology, 2, pp. 179-190.

[47] Alisi , C., Musella, R., Tasso, F., Ubaldi, C., Manzo, S., Cremisini, C., \& Sprocati, A. 2009. Bioremediation of Diesel oil in a co-contaminated soil by bioaugmentation with a microbial formula tailored with native strains selected for heavy metal resistance. Science of Total Environment, 407, pp. 3024-3032.

[48] Silva , E., Fialho, A., Sa-Correia, I., Burns , R. G., \& Shaw, L. 2004. Combined bioaugmentation and biostimulation to clean up soil contaminated with high concentrations of atrazine. Environmental Science and Technology, 38, pp.632-637.

[49] USEPA. 1997. United State Environmental Protection Agency. Retrieved June 15, 2020, from United State Environmental Protection Agency: http://www.epa.gov/osw/conserve/rrr/composting/pubs/bioremed.pdf

[50] Atagana, H. 2008. Compost bioremediation of hydrocarbon-contaminated soil inoculated with organic manure. African Journal Biotechnology, 7, pp. 1516-1525.

[51] Garcia-Gomes, A., Roig, A., \& Bernal, M. 2003. Composting of the solid fraction of live oil mill wastewater with olive leaves: Organic matter degradation and biological activity. Bioresource Technology, 86, pp. 59-64.

[52] Cajhaml, T., Bhatt, M., Sajek, V., \& Mateju, V. 2002. Bioremediation of PAH-Contaminated soil by composting: a case study. Folia Microbiologica, 47, pp.696-700.

[53] Barker, A., \& Bryson, G. (2002). Bioremediation of heavy metals and organic toxicants by composting. The Scientific World Journal, 2, pp.407-420.

[54] Frazer, C. (2020). Bioremediation of Heavy Metals. Retrieved from Bioremediation of Heavy Metals: http://www.bvsde.paho.org/bvsarp/i/fulltext/biore/biore.pdf

[55] Pare, T., Dinel, H., \& Schnitzer, M. 1999. Extractability of trace metals during composting of biosolids municipal wastes. Biology and Fertility of Soils, 29, pp. 31-37.

[56] Ling, C., \& Isa, M. (2006). Bioremediation of oil sludge contaminated soil by sompoting with sewage sludge. Journal of Scientific and Industrial Research, pp. 364-369.

[57] Ahiamadu, N., \& Suripno, S. 2009. Bioremediation of crude oil contaminated soil by composting using wood shaving as bulking. Society of Petroleum Engineers, 15, pp. 237-241. doi:10.2118/122744-2

[58] Kalogerakis, N. 2005. Exsitu Bioremediation of contaminated soils: Soil and sediment remediation mechanics, technologies and application. In Lens, P (ed).

[59] Irvine, D., \& Frost, H. 2003. Bioremediation of soils contaminated with industrial wastes a report on the state of the art in bioremediation. Luven: Bioremediation . Retrieved 9.15, 2020, from http://www.uhu.es/masteria/master/material/402.pdf.

[60] Paudyn, K., Ruther, A., Rowe, R., \& Pilard, J. 2008. Remediation of hydrocarbon contaminated soils in the Canadian artic by land farming. Cold Regions Science and Technology, 53, pp.102-114.

[61] Mmom, P., \& Deekor, T. 2010. Assessing the effectiveness of land farming in the remediation of hydrocarbon polluted soils in the Niger Delta, Nigeria. Research Journal of Applied Sciences, Engineering and Technology, 2, pp.654-660.

[62] EPA. 2000. Land farming. Environmental Protection Agency, 55. Retrieved from http://www.epa.gov/oust/pubs/tum_ch5. pdf. 
[63] Lal, R., Hall, G., \& Miller, F. 1989. Soil Degradation: I. Basic Processes. Land Degradation and Development, 1, pp.51-69.

[64] Khan, F. I., Husain, T., \& Hejazi, R. 2004. An overview and analysis of site remediation technologies. Journal of Environmental Management, 71(2), pp.95-122.

[65] Hejazi, R. F. 2002. Oily Sludge Degradation Study under Arid Conditions Using a Combination of Landfarm and Bioreactor Technologies. Faculty of Engineering and Applied Sciences. St. John's Canada: University of Newfoundland.

[66] Filler, D. 2001. Integral biopile components for successsful bioremediation in the Artic. Cold Region Science and Technology, 32(2), pp. 143-156.

[67] Erickson, L. E., Banks, M. K., Davis, L. C., Schwab, A. P., Muralidharan, N., Reilley, K., \& Tracy, J. C. 1999. Using Vegetation to Enhance In Situ Bioremediation. Kansas: University Manhattan, KA.

[68] Nwoko, C. 2010. Trends in phytoremediation of toxic element and organic pollutants. African Journal of Biotechnology, 9, pp. 6010-6016.

[69] Mohanty, M., Dhai, N., Patra, P., Das, B., \& Reddy, P. 2010. Phytoremediation a novel approach for ultilization of iron-ore wastes. Reviews in Environmental Contamination and Toxicology, 206, pp. 29-47.

[70] Jadia , C., \& Fulekar, M. 2008. Phytotoxicity and remediation of heavy metals by alfalfa (medicago sativa) in soil-vermicompost media. Remediation of Toxic Metals, 67.

[71] Kaushik, C., Raj, K., \& D'Souza, S. 2008. Phytoremediation of 137 Cesium and 90 Strontium from solutions of low-level nuclear waste b vetiveria zizanoids. Ecotoxicology and Environmental Safety, 69, pp. 206-311.

[72] Weishaar, J., Tsao, D., \& Burken, J. 2009. Phytoremediation of BTEX hydrocarbons : potentila impacts of diumal groundwater fluctuation on microbial degradation. International Journal of Phytoremediation, 11, pp. 509-523.

[73] Chen, C. H., Liu, P. G., \& Whang, L. 2019. Effects of Natural Organic Matters on Bioavailability of Petroleum Hydrocarbons in Soil-WaterEnvironment. Chemosphere, 233, pp. 843-851.

[74] Denys, S., Rollin, C., Guillot, F., \& Baroudi, H. 2006. In-situ phytoremediation of PAHs contaminated soils following a bioremediation treatment. Water, Air and Soil Pollution: Focus, 6, 299-315.

[75] Agnello, A., Bagard, M., van Hullebuscha, E., Espositob, G., \& Huguenot, D. 2016. Soil by natural attenuation, phytoremediation, bioaugmentation and bioaugmentation-assisted phytoremediation. Science of the Total Environment, 563-564, pp.693-703. doi:10.1016/j.scitotenv.2015.10.061

[76] Gerhardt, K., Huang, X., Glick, B., \& Greenberg, B. 2009. Phytoremediation and rhizoremediation of organic soil contamination: Potential and challenges. Plant Science, 176, pp. 20-30.

[77] Green, C., \& Hoffnage, A. 2004. Phytoremediation field studies database for chlorinated solvents, pesticides, explosives, and metals. University of Arizonal. Washington, DD: U.S Environmental Protection Agency, Office of Superfund Remediation and Technology Innovation . Retrieved May 22, 2020, from <http://www.cluin.org/download/studentpapers/hoffnagle-phytore mediation.pdf.

[78] Olsen, P., Wong, T., Leigh, M., \& Fletcher, J. 2003. Allowmetric modelling of plant growth and its application in rhizosphere remediation of soil contaminants . Environmental Science and Technology, pp.638-643.

[79] Griffiths, R. A. 1995. Soil Washing Technology and Practice. Journal of Hazardous Materials, 40, 175-189. 


\title{
PREGLED BIOREREMEDIJACIJE KONTAMINIRANIH HIDROMORFNIH ZEMLJIŠTA U PODRUČJU DELTE REKE NIGER U NIGERIJI
}

\author{
Ehiomogue O. Precious ${ }^{1}$, Ahuchaogu I. Israel ${ }^{2}$, Ahaneku I. Edwin ${ }^{1}$ \\ ${ }^{I}$ Department of Agricultural and Bioresources Engineering, College of Engineering and \\ Engineering Technology, Michael Okpara University of Agriculture, Umudike, Abia State, \\ Nigeria. \\ ${ }^{2}$ Department of Agricultural and Food Engineering, Faculty of Engineering, \\ University of Uyo, Akwa-Ibom State, Nigeria.
}

Sažetak: Tehnologije bioremedijacije su ekološki pristup za tretman zagađenih zemljišta. U ovom radu se razmatraju mnogobrojni napori i metode za sanaciju od različitih naučnika za poboljšanje ili popravku negativnih uticaja zagađenja životne sredine sirovom naftom.

Kontaminacija celokupne životne sredine (vazduh, zemljišta, vode i biosfera) sirovom naftom postala je najvažniji interes u delti reke Niger (ukupna dužina reke je $4184 \mathrm{~km}$ ). Uz česte izveštaje o izlivanju nafte na području delte reke Niger, potrebno je potražiti isplativ metod za sanaciju zemljišta pogođenih izlivanjem sirove nafte. Studije su otkrile promenljive uticaje toksičnosti nafte na životnu sredinu i populaciju. Zagađenje zemljišta uzrokovano je uglavnom nekontrolisanom pojavom curenja nafte iz ukopanih podzemnih rezervoara i cevi.

Najčešći konvencionalni metod za sanaciju kontaminiranog zemljišta je uklanjanje-iskop delova zagađenih zemljšta sa formiranjem deponija, ili spaljivanje zagađenih delova, i druge tehnologije koje su široko primenljive.

Kontaminirana mesta predstavljaju pretnju za život ljudi zbog ozbiljnih zdravstvenih problema prouzrokovanih nepovoljnim zdravstvenim efektima izlaganja zagađenju zemljišta. Jednom kada se zagađenje otkrije, moraju se izvršiti: strategije procene, odrediti vrstu i način uzorkovanja, hemijske analize, procena parametara zagađenja i njihov efekat.

Nekoliko tehnologija i parametara je razvijeno za ispitivanje zemljišta zagađenog derivatima nafte (ugljovodonici), ali ovaj problem i dalje postoji.

Ključne reči: ugljovodonici iz nafte, prirodno slabljenje, bioaugmentacija, fitoremedijacija, Biopiles tehnologija.

Prijavljen:

Submitted: 09.03.2021.

Ispravljen:

Revised: 20.6.2021.

Prihvaćen:

Accepted: 25.07.2021. 